\title{
Proposed Concept of Modeling and Empowerment of Street Vendors in Jombang Regency
}

\author{
$1^{\text {st }}$ Meriana Wahy u Nugroho \\ Department of Civil Engineering, \\ Hasyim Asy'ari University, \\ Jombang, Indonesia \\ e-mail: wahyu@ ringin-contong.com
}

\author{
$2^{\text {nd }}$ Abdiy ah Amudi \\ Department of Civil Engineering, \\ Hasyim Asy'ari University \\ Jombang, Indonesia \\ e-mail: abdiyah.amudi@yahoo.com
}

\begin{abstract}
The existence of street vendors (PKL) is unavoidable and almost every country in the world faces this problem, including countries as advanced as America and Europe countries. In Indonesia, the street vendors have also been met on the roadsides of the city. Viewing the growing progress, the presence of street vendors will bring up new problems to the local government. Moreover, the problem faced is the arrangement and empowerment of street vendors. Of course, it is for street vendors who do not have a license to sell in public spaces. The longterm goal of this research is to produce a model for the arrangement and empowerment of Jombang regency $S$ treet vendors and will be implemented for one year. The findings of this study are expected to be able to contribute for structuring and empowering the street vendors in Jombang regency, so that later it can also support the religious tourism sector in Jombang.

This research uses the qualitative method and the data sources are informants, they are street vendors and society in Jombang regency and local government who handle the business of street vendors in Jombang regency. Data are collected by observation, interview, recording, and taking note technique. Techniques used for analyzing the data are descriptive analysis techniques and content analysis. The validity tests used in this research are triangulation, verifications, and prolong research by observing continuously.

Based on the result of research and discussion, it can be concluded that the arrangement of street vendors in Jombang regency from interviewing the stakeholder, it gets priority scale obtained by using Analytic Hierarchy Process (AHP) from 5 criteria (spatial, public order, economic, social and environment), those are spatial planning 35.9\%, public regularity $22.6 \%$, economy $17.8 \%$, social $14.8 \%$, and environment $8.9 \%$. Therefore, the researchers plan alternative model arrangement of street vendors at each point of street vendors
\end{abstract}

location spread in Jombang Regency, they are at 5 locations.
Keywords: model, street vendors arrangement, street vendors empowerment, arrangement and empowerment model

\section{INTRODUCTION}

The limit of formal employment for fulfilling society's need in Indonesia causes the emergence of informal jobs, such as street vendors. This informal job is as security valve, or the last bumper for solving the national economy matters from the regional or global crisis since 2007. It is proven can improve the society's economy.

The existence of street vendors has two sides, positive and negative. The positive side is for empowering local economy. Street vendors are considered as 'savior' because they have provided employment, have given convenience for society to get some items for the low price, have increased the city attraction, and also have made the city more 'alive'. For low income society segment, the existence of street vendors is very beneficial because they can fulfill the products and items needed for the relatively affordable price. Beside, the existence of street vendors also influences to boost the economic dynamics [1].

While the negative side, street vendors are considered as 'disturbance' which makes the city is messy, disturbing the regularity and security, dirty, and disrupt the city beauty. The existence of street vendors often regarded illegal, because they use public spaces and is not in accordance with the city vision which majority emphasizes the clean, beautiful, and tidy city [2]. Therefore, 
street vendors often become the main target for policies of city government, such as dragging and relocation.

In some big cities, there are reports on the success of street vendors' arrangement, for example Surabaya, Surakarta and Yogyakarta which succeed to arrange them by the regional approach. Some cities which have been arranging and can be appreciated up to now are like Jakarta and Bandung. From this street vendors' arrangement, it is hoped to be the reference for other regions, especially some cities which develops in economy growth, to arrange and empower the street vendors without causing tension of every party [3].

From the problems explained above, this research is important to be done. This research is aimed to provide the model concept of street vendors' arrangement and empowerment in Jombang district. Next, it is aimed at the implementation of street vendors' arrangement and empowerment in Jombang district in order to be more organized, orderly, beautiful, and comfortable. Also, it can cause the street vendors location as the destination for a religious city tour.

\section{METHOD}

This research uses the descriptive qualitative method. The data sources are primary and secondary data. The technique for collecting the data are observation, interview, and documentation.

This research entitled 'Street Vendors' Proposed Concept of Modeling and Empowerment in Jombang Regency' consists of a model arrangement in accordance with standards and principles used by the research of government's policy addressed to the society [4]. To ease the research in related to the scope of activities identified by descriptive qualitative method quantitative paradigm is describing qualitative data in the form of matrix, pictures or analogue graphs [5]. Physical data of area identified by the mapping method are used for mapping the spread of street vendors in research location. It uses triangulation analysis by the method of (Analys is Hierarcy Process). While the variables used in this research is the layout factor, public regularity, economy, social, and environment [6].

According to Shankar and Uday in Pemodelan Sistem [7], generally the model construction phases are done by the stages below:

1. Problem definition

2. Early model formulation

3. Model validation

4. Modelreformulation (if it is seen inappropriate)

5. Model application (model usage).

Model of construction process can be seen interactively by using diagram such as the picture 1 below.

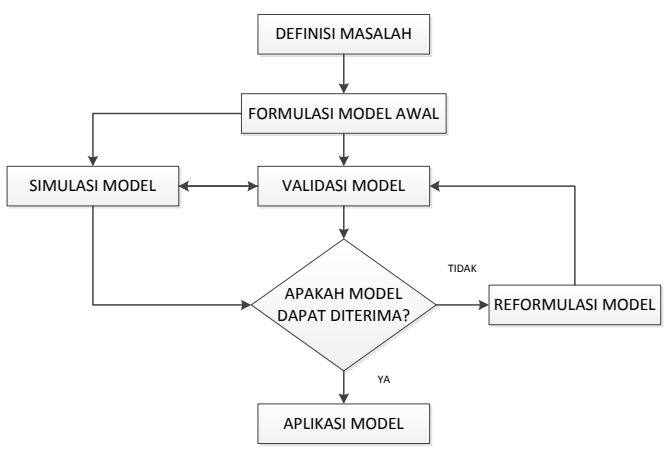

Fig. 1. Model construction process

\section{FINDING AND DISCUSSION}

A. General Illustration of Street Vendors in Jombang Regency

Street vendors analyzed in this research are five points spread in Jombang regency, they are in Jombang district two points (in Jombang town square and Jombang stadium), Ploso district one point, Mojoagung one point, and Diwek district one point. While the characteristics of street vendors in each point are:

1. Jombang Town Square

A number of street vendors in Jombang town square about 240 people, with the variant items for selling such as food and beverage, cigarette, candy, toys for children, and so forth. The media used for selling are wagon, car, and motorcycle. Their operational time for selling in a usual day is from 10.00 a.m. - 09.00 p.m. and in the holiday is from 06.00 a.m. - 12.00 a.m. From the observation, the most crowded visitors are at 06.00 p.m. - 09.00 p.m.

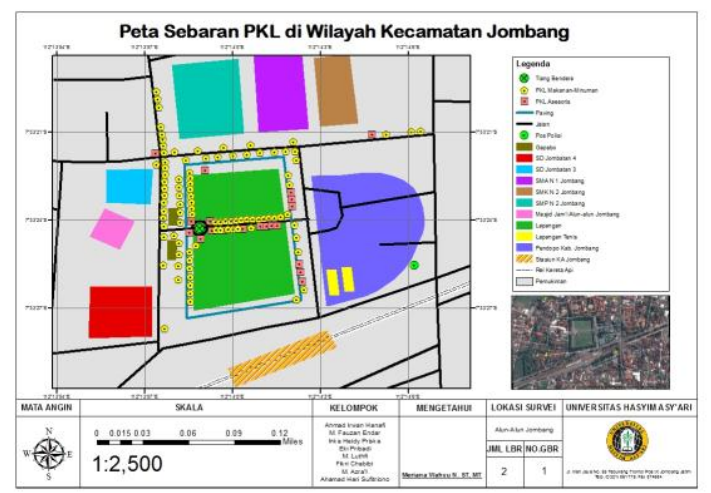

Fig 2. Existing map of street vendors in Jombang Town 
Square

2. Jombang Stadium

A number of street vendors in Jombang stadium are about 100 people. The variant items to sell are food and beverage, cigarette, candy, toys for children, and so forth. The media used for selling are permanent and temporary stalls such as wagon, car, and motorcycle. Operational time for selling is from 10.00 a.m. -09.00 p.m.

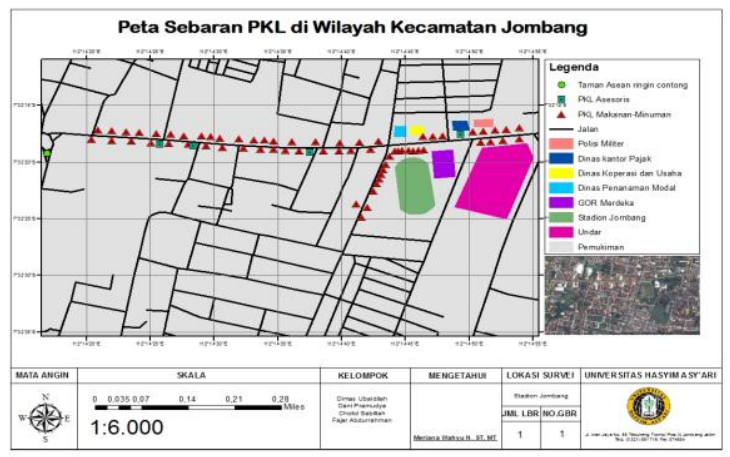

Fig 3. Existing map of street vendors in Jombang stadium

\section{Ploso District}

A number of street vendors in Ploso district are about 200 people. Because the place closes to Ploso traditional market, so the variant items to sell is similar to items sold in the traditional market, such as food and beverage, cigarette, candy, toys for children, and so forth. The media used for selling are wagon, car, and motorcycle. Operational time for selling is from 03.00 p.m. 09.00 p.m.

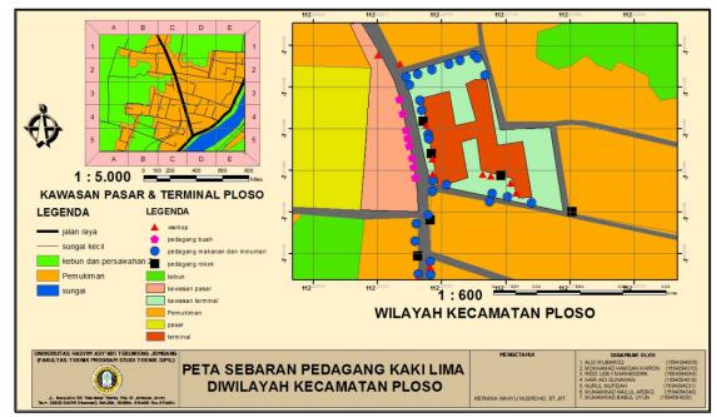

Fig 4. Existing map of street vendors in Ploso district

\section{Diwek district}

A number of street vendors in Diwek district are about 200 people. Because of the place next to Gus Dur grave religious tourism, UNHASY, and schools, so the majority variant items to sell is such as food and beverage, cigarette, candy, toys for children, and so forth. The media used for selling are permanent and temporary stalls such as wagon, car, and motorcycle. Operational time is various.

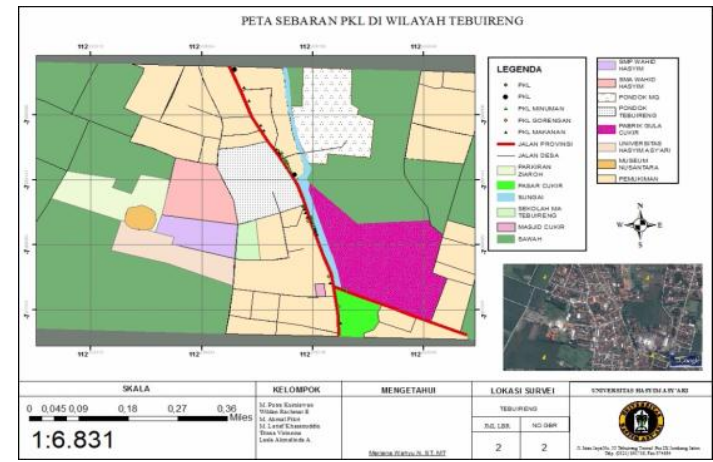

Fig 5.. Existing map of street vendors in Diwek district

\section{Mojoagung district}

A number of street vendors in Diwek district is about 200 people. The variant items for selling such as food and beverage, cigarette, candy, toys for children, and so forth. The media used for selling are wagon, car, and motorcycle. Their operational time for selling in a usual day is from 10.00 a.m. -09.00 p.m. and in the holiday is from 06.00 a.m. - 12.00 a.m. From the observation, the most crowded visitors are at 06.00 p.m. - 09.00 p.m.

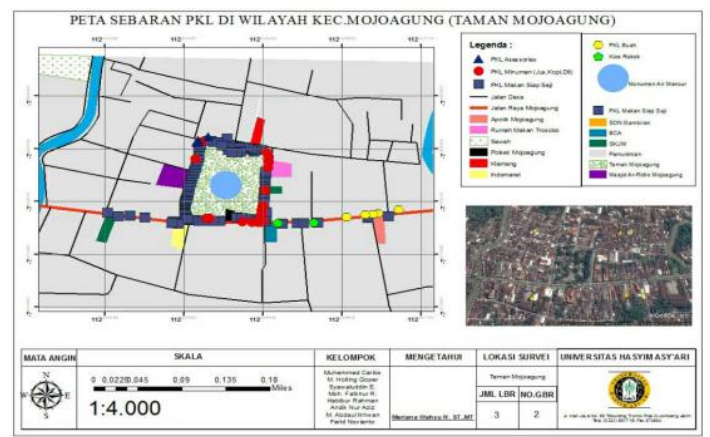

Fig. 6. Existing map of street vendors in Mojoagung district 


\section{B. Triangulation Analysis}

T ABLE 1 PHYSICAL SHAPE OF STREET VENDORS' SELLING MEDIA IN JOMBANG REGENCY

\begin{tabular}{|c|c|}
\hline No & Criteria \\
\hline 1 & $\begin{array}{l}\text { a. The model of street vendors' enterprise } \\
\text { facilities should have suitability with the } \\
\text { building facades and it seems transparent } \\
\text { so that it does not disturb the visual } \\
\text { aesthetic at every spreading point of street } \\
\text { vendors. }\end{array}$ \\
\hline & $\begin{array}{l}\text { b. The existence of street vendors should } \\
\text { have patterns which are adapted to the } \\
\text { existence of building surround them. }\end{array}$ \\
\hline 2 & $\begin{array}{l}\text { The pavement should have the enough large to } \\
\text { be used by the pedestrians. }\end{array}$ \\
\hline 3 & $\begin{array}{l}\text { Street furniture must be provided to complete } \\
\text { the facilities, and also to prevent street vendors } \\
\text { using all space of pavement to do selling } \\
\text { activities at once. }\end{array}$ \\
\hline 4 & $\begin{array}{l}\text { Vegetation plantation should be adapted to its } \\
\text { place and purpose character. In this case, } \\
\text { vegetation can be functioned as the border } \\
\text { plants. }\end{array}$ \\
\hline
\end{tabular}

5 Street vendors' enterprise facilities should be able to be dismantled and set up at once.

Street vendors' enterprise facilities should have an identical physical appearance.

Street vendors' enterprise facilities wide must not be over than $2 \times 2$ meters per lot.

Street vendors should be grouped according to kinds of sold items. designed to have similar shape with the shape of basic geometry in accordance with the building surround them, street vendors' stalls are designed to have suitable roof element with the building surround them, the transparent impression is emerged by maximizing aperture by negating the wall element in street vendors' enterprise facilities using the matching color composition with building surround them.

The pavement is designed with dimension in accordance with pedestrian space which covers the visual and motion need. Pavement dimension can be expanded by using closed ditch when street vendors are doing some activities, they can use the inner pavement space, whereas the pedestrians are provided outside pavement space to use.

The pavement is completed with street furnitures, such as bench, street lights, and permanent trash bin. It can prevent street vendors to use all space of pavement.

It should use the vegetation which has length $<5 \mathrm{~m}$ in order not to block some views of the building. Kind of vegetation can be used are shrubs, bushes, such as bougainvillea, jasmine or hibiscus. Open vegetation concept at length of 5 - 15 meters to construct a view and as an access point from the street toward the pavement.

Street vendors' enterprise facilities allowed to use are temporary stalls or wagons which can be dismantled and set up at once. Wagons must be dismantled and brought home after the selling activities are done. Street vendors' wagons are completed with wheels so that it can easily to dismantle. Shading tents also use the system of dismantles and set up at once.

Street vendors' temporary stalls or wagons should be formed similar each other to fulfill harmonious and appropriate principle. The street vendors' temporary stalls should have the space for saving the luggage. Tents of street vendors' stall are made from galvalum/aluminum. The shapes are adapted with the building surround in order to establish appropriate region image. Street vendors' temporary stalls are opened-made without banner covering stalls bodies.

One unit of street vendors' enterprise facilities should have maximum large of $2 \times 2$ meters, based on a determined lot in accordance with pavement pattern. Street vendors allowed having more than one lot by following the standard rule of lot size.

Food is kind of sold items which often found to be sold by street vendors in Jombang regency. So, all of the food street vendors should be placed in the same row. Whereas street vendors who sell other items are placed in other different rows. Food street vendors are grouped in order to ease the garbage controlling and raw material distribution.

The location of street vendors' temporary stalls is regularly based on available location design. Street vendors are only allowed to use the body of the street at night. 


\section{Analysis Hierarchi Process (AHP) Finding}

From result identification criteria of three level respondents, it can be explained that the first level is the main goal, determination of priority scale of street vendors handling strategy in Jombang regency. The second level consists of five factors, they are: spatial, public regularity, economy, social, and environment. The third level is alternative handling. Here is all of the determination of priority scale hierarchy.

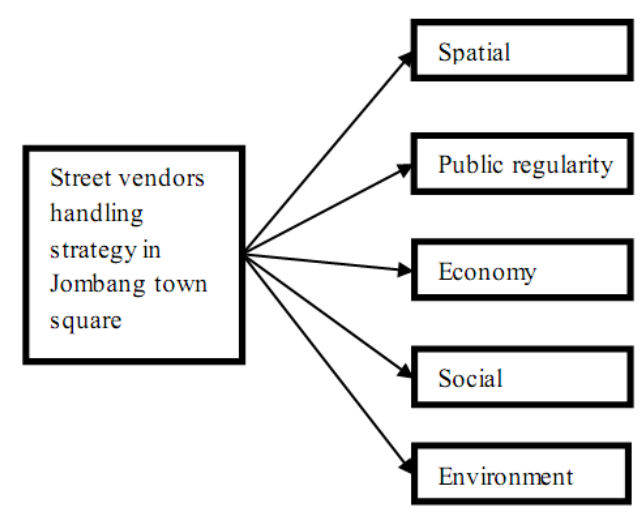

Fig 7. Priority hierarchy

From the interview with stakeholders it is obtained the sequence of priority scale which is gained by using Analytic Hierarchy Process (AHP) method from five criteria (spatial, public regularity, economy, social, and environment) that the respondent assessment toward some criteria shows spatial factor criterion has the highest level of influence, with the value of $0,359(35,9 \%)$, then it is followed by the public regularity factor with the value of $0,226(22,6 \%)$, economy factor with the value of $0,178(17,8 \%)$, social factor with the value of $0,148(14,8 \%)$ and the last is environment factor with the value of $0,089(8,9$ $\%)$.

TABLE 2. PRiority SCALE CALCULATION REsult

\begin{tabular}{cc}
\hline Criteria & Value \\
\hline Spatial & 0,359 \\
Public regularity & 0,226 \\
Economy & 0,178 \\
Social & 0,148 \\
Environment & 0,089 \\
Total & 1,000 \\
\hline
\end{tabular}

After getting the priority scale calculation result above, the street vendors design arrangement can be planned, and it is also hoped to solve the existing problems.

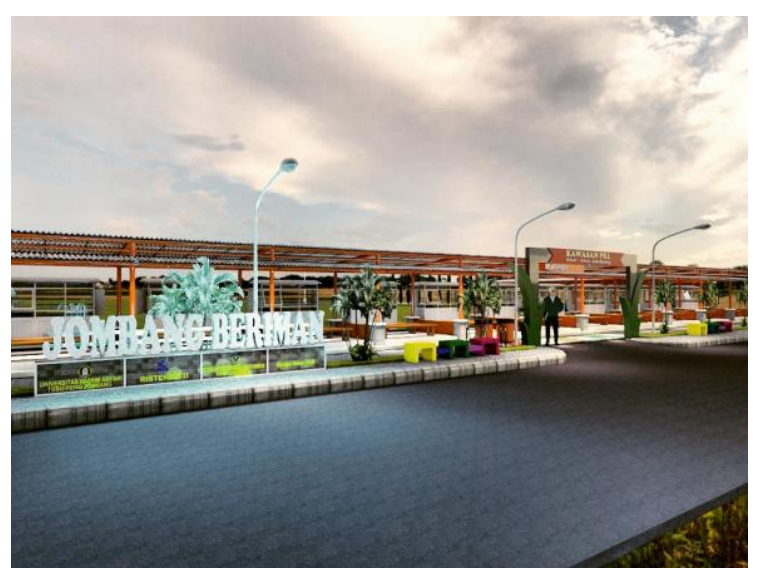

Fig 7. street vendors design An arrangement in Jombang Town Square

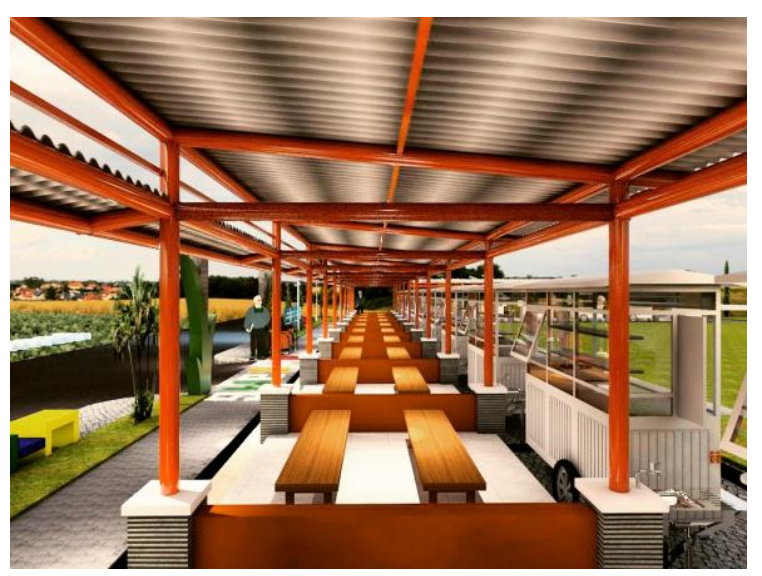

Fig 8. street vendors design An arrangement in Jombang Town Square

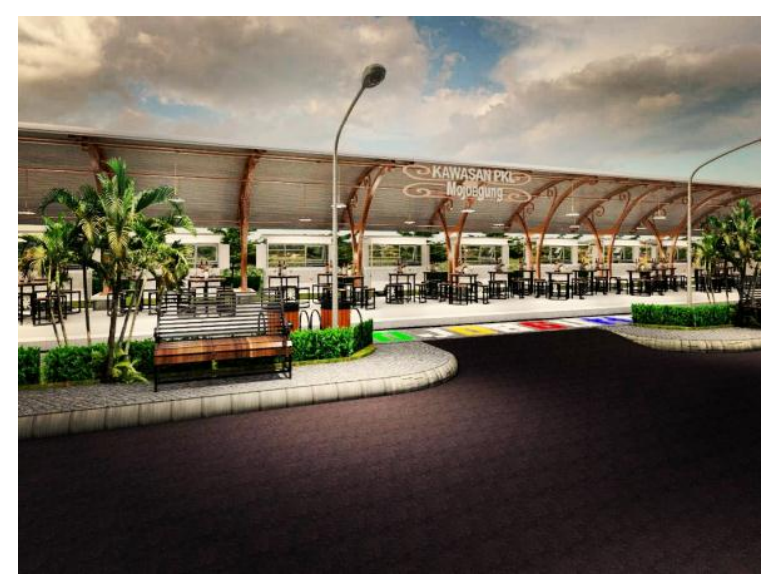

Fig 9. street vendors design $\mathrm{B}$ arrangement in Mojoagung district 


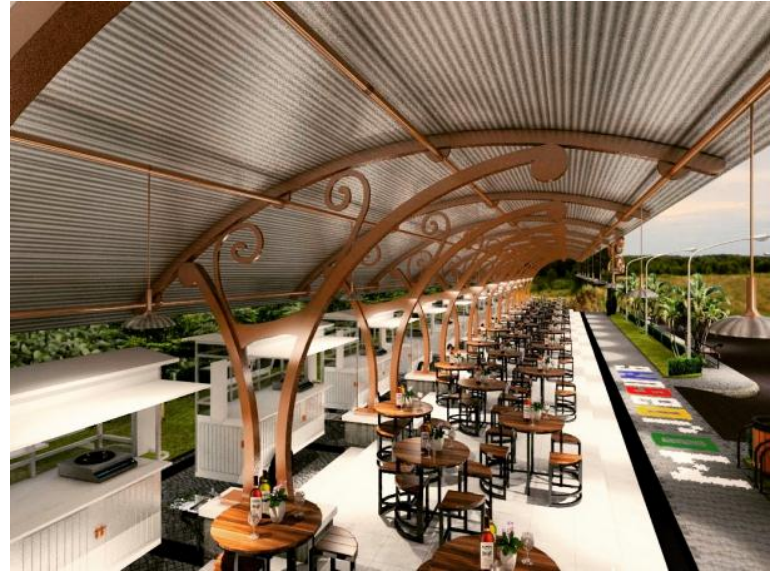

Fig 10. street vendors design $\mathrm{B}$ arrangement in Mojoagung district

\section{CONCLUSION}

Based on the above results of research and discussion of the previous subchapter about street vendors design arrangement concept and empowerment in Jombang regency, it can be concluded:

1. From the interview with stakeholder it is obtained the sequence of priority scale which is gained by using Analytic Hierarchy Process (AHP) method from five criteria (spatial, public regularity, economy, social, and environment), the results are spatial factor with the value of $35,9 \%$, public regularity factor with the value of $22,6 \%$, economy factor with the value of $17,8 \%$, social factor with the value of $14,8 \%$ and the last is environment factor with the value of $8,9 \%$. So that, the researcher plans to design alternative street vendors' arrangement at every point of street vendors spread in Jombang regency, at 5 locations.

2. The arrangement concept is planned can be gained from the triangulation analysis below:

a. The model of street vendors' enterprise facilities are designed to have similar shape with the shape of basic geometry in accordance with the building surround them, street vendors' stalls are designed to have suitable roof element with the building surround them, the transparent impression is emerged by maximizing aperture by negating the wall element in street vendors' enterprise facilities using the matching color composition with building surround them.

b. The pavement is designed with dimension in accordance with pedestrian space which covers the visual and motion need. Pavement dimension can be expanded by using closed ditch when street vendors are doing some activities, they can use the inner pavement space, whereas the pedestrians are provided outside pavement space to use.

c. The pavement is completed with street furnitures, such as bench, street lights, and permanent trash bin. It can prevent street vendors to use all space of pavement.

d. It should use the vegetation which has length $<5 \mathrm{~m}$ in order not to block some views of the building. Kind of vegetation can be used are shrubs, bushes, such as bougainvillea, jasmine or hibiscus. Open vegetation concept at length of 5 - 15 meters to construct a view and as an access point from the street toward the pavement.

e. Street vendors' enterprise facilities allowed to use are temporary stalls or wagons which can be dismantled and set up at once. Wagons must be dismantled and brought home after the selling activities are done. Street vendors' wagons are completed with wheels so that it can easily to dismantle. Shading tents also use the system of dismantles and set up at once.

f. Street vendors' temporary stalls or wagons should be formed similar each other to fulfill harmonious and appropriate principle. The street vendors' temporary stalls should have the space for saving the luggage. Tents of street vendors' stall are made from galvalum/aluminum. The shapes are adapted with the building surround in order to establish appropriate region image. Street vendors' temporary stalls are opened-made without banner covering stalls bodies.

g. One unit of street vendors' enterprise facilities should have maximum large of $2 \times 2$ meters, based on a determined lot in accordance with pavement pattern. Street vendors allowed having more than one lot by following the standard rule of lot size.

h. Food is kind of sold items which often 
found to be sold by street vendors in Jombang regency. So, all of the food street vendors should be placed in the same row. Whereas street vendors who sell other items are placed in other different rows. Food street vendors are grouped in order to ease the garbage controlling and raw material distribution.

i. The location of street vendors' temporary stalls is regularly based on available location design. Street vendors are only allowed to use the body of the street at night.

\section{REFERENCES}

[1] Dyrness, Grace Roberts (2001). Policy on the Streets: A Handbook for the Establishment of Sidewalk-Vending Programs. University of Southern California: Center for Religion and Civic Culture.

[2] Bhowmik, Sharit K. (2005). "Street vendors in Asia: A review." Economic and Political Weekly May 28June 4, pp. 2256-2264.

[3] ILO (2007). Equality at Work: Tackling the Challenges. Global Report Under the Follow-up to the ILO Declaration on Fundamental Principles and Rights at Work.

[4] Schwartz, Mark.S and Arche B. Carrol (2003). Corporate Social Responsibility: A Three- Domain Approach. Business Ethics Quarterly, Vo. 13, No.4 (Oct, 2003), pp. 503-530.

[5] Saaty TL, 1980, The Analytic Hierarchy Process, NY, McGraw Hill

[6] Bhavan, Nirvan (tanpa tahun). National Policy on Urban Vendors, 2009. New Delhi: Ministry of Housing \& Urban Poverty Alleviation.

[7] Shankar, Uday (2014). Socio-Economic Rights (SER) in India: Responses during Economic Crisis. Indian Institute of technology Kharagpur. 